\title{
AQUILEIENSES CLERICI QUASI CHORUS BEATORUM HABENTUR (HIERONIM, KRONIKA, ROK 374). PRZYKLAD ŻYCIA RELIGIJNEGO DUCHOWNYCH POD KONIEC IV WIEKU**
}

W pierwszych wspólnotach chrześcijańskich, dziewictwo dla królestwa Bożego, uważane za uprzywilejowaną drogę i charyzmat (por. Mt 19, 12; 1 Kor 7, 29-38), praktykowane było zarówno przez kobiety jak i przez mężczyzn jako osobiste powołanie; było ono uznane przez Kościół i chronione przez biskupa, ale nie zinstytucjonalizowane w żaden sposób. Następnie, dziewice formowały - z pewnością od IV w. - w Kościele ordo, to znaczy grupę uznaną i poddaną bezpośrednio władzy biskupa. W niektórych zestawieniach, pojawiają się one obok wdów i innych ordines Kościoła. Jest możliwe, że od III w. niektóre dziewice prowadziły wspólne życie, ale były to odosobnione przypadki. Wspominane są za to przypadki wspólnego życia osób obu płci żyjących w celibacie, a także takich osób i duchowieństwa, która to praktyka była podejrzewana o prowadzenie do nadużyć.

Jeśli chodzi o duchownych, to zjawiskiem powszechnym było, iż kandydaci do posługi kapłańskiej byli żonaci - zazwyczaj żyjący we wstrzemięźliwości po wychowaniu dzieci - nie było jednak czymś wyjątkowym, że niektórzy kandydaci zostawali duchownymi nie będąc wcześniej żonatymi, jak np. w II w. Meliton z Sardes (,eunuch” dla Pana) a w III w. Cyprian (który w każdym razie nie ożenił się po swoim chrzcie), czy Korneliusz, o którym Cyprian mówi, że żył w „dziewiczej czystości” (virginalis continentia) ${ }^{1}$, i oczywiście Orygenes. W tle wyświęconych kapłanów, spotykamy często model lewity, nie tylko ze względu na wstrzemięźliwość, ale także ze względu na niepodejmowanie aktywności zawodowej oraz na praktykę wspólnej modlitwy w samym sanktuarium lub w jego pobliżu. Jeśli prawdąjest, że Chrystus poprosił swoich uczniów nie tylko o opuszczenie ziemskich dóbr („pola” - Mk 10, 29 i Mt 19, 29), ale także „domu, braci i sióstr, ojca, matki i dzieci” (Łk 18, 29 dorzuca jeszcze ,żony") - to ostatnie wyrzeczenie nie było wymagane, z wyjątkiem

* Prof. dr hab. Agnès Bastit-Kalinowska - maître de conférence Université de Lorraine (Metz), członek Institut Universitaire de France; e-mail: agnes.bastit@univ.lorraine.fr.

${ }^{* *}$ Serdecznie dziękuje Pani Ewie Deskur-Kalinowskiej za pomoc językową przy redakcji tekstu.

${ }^{1}$ Cyprianus, Epistula 55, 8, 3, ed. Bayard (Chanoine): Cyprien, Correspondance, vol. 2, Les Belles Lettres, Paris 1925, 136. 
czasowego, od żydowskich kapłanów-lewitów - Orygenes i Cyprian wnioskują z tego, że kapłani Kościoła powinni prowadzić życie trzeźwe i ubogie; biskup bowiem i jego współpracownicy są odpowiedzialni za służbę ołtarza, a zatem mają misję nieustannego dziękczynienia Bogu, ale także wstawiania się za powierzonym sobie ludem (Tradycja Apostolska, Orygenes) ${ }^{2}$. Autor z którego badań korzystam w niniejszym opracowaniu, Enrico Cattaneo, podsumowując te wstępne rozważania dotyczące trzech pierwszych wieków, posuwa się do sugestii, że począwszy od IV w., to nie członkowie kleru czerpali swoją duchowość od mnichów, lecz na odwrót, to mnisi byli tymi, którzy radykalizowali duchowość duszpasterzy³.

W każdym razie, od połowy IV w. można zaobserwować zbliżenie między klerem a mnichami oraz pojawiającymi się formami życia apostolskiego, które świadomie przyjmują cechy monastyczne. Znany jest przypadek Bazylego z Cezarei, który w latach 60-tych IV w. przebył drogę od życia w klasztorze (poza miastem) do posługi biskupiej, zachowując częściowo swą duchowość i zwyczaje monastyczne, co jest jeszcze bardziej widoczne w przypadku Marcina $\mathrm{z}$ Tours na Zachodzie (koniec IV w.) ${ }^{4}$. W tym samym czasie, zgodnie ze świadectwem Ambrożego, Euzebiusz z Vercelli zaprowadził wspólnotę życia religijnego duchownych, którzy byli równocześnie mnichami i duszpasterzami, łącząc ,posługę kapłańską” (clericorum officia) z monastycznym sposobem życia (monachorum instituta) ${ }^{5}$. Później (przełom IV i V w.) Paulin z Noli ze swoją żoną, otoczeni kilkoma bliskimi osobami, także połączy sprawowanie posługi kapłańskiej ${ }^{6} \mathrm{z}$ życiem monastycznym we spólnocie blisko sanktuarium w Noli; w tym samym czasie, Augustyn również, po wielu doświadczeniach, przyjmie model z Vercelli w swoim monasterium clericorum ${ }^{7}$.

W niniejszym opracowaniu chciałabym zwrócić uwagę na mało znany (oprócz znawców północno-wschodniej Italii w okresie późnego antyku ${ }^{8}$ ) eks-

${ }^{2}$ Por. E. Cattaneo, I ministeri nella Chiesa antica. Testi patristici dei primi tre secoli, Milano 1997, 133-144, zob. francuską wersję (aktualizowaną): Les ministères dans l'Église ancienne, Paris 2017, 113-122.

${ }^{3}$ Por. tenże, E. Cattaneo, Una lettura sacerdotale dei salmi, „La civiltà cattolica” nr 3898 (2012) 4, 343-353.

${ }^{4}$ Odnośnie Bazylego zob. A. Persić, Basilio monaco e vescovo: una sola chiamata per tutti $i$ cristiani, w: Per foramen acus. Il cristianesimo antico di fronte alla pericope evangelica del „giovane ricco”, Studia Patristica Mediolanensia 14, Milano 1986, 160-207.

${ }_{5}^{5}$ Ambrosius Mediolanensis, Epistula extra coll. 14, 71, ed. M. Zelzer, CSEL 82, Vienne 1982, 273.

${ }^{6}$ Paulin od 395 mieszkał z żoną i kilkoma bliskimi w miejscu, które nazwał monasterium [Epistula (Ad Severum) 5, 15]. Biskupem Noli został dopiero ok. 410 r., prawdopodobnie po śmierci żony. Por. J.T. Lienhard, Paulin de Nole, DSp XII 592-602.

${ }^{7}$ Possidius, Vita Augustini 5, PL 32, 37: „factus ergo presbyter monasterium intra ecclesiam mox instituit”; tamże 11, PL 32, 42: ,cum sancto Augustino (episcopo) in monasterio Deo servientes et Ecclesiae Hipponensi, clerici ordinari coeperunt".

${ }^{8}$ Zob. R. Bratož, Frühes Mönchtum in den Donau- und Balkanprovinzen. Eine Bestandsaufnahme, w: Acta congressus internationalis XIV archaeologiae Christianae, a cura di R. Harreither - Ph. Pergola - R. Pillinger - A. Pülz, pars 1, Città del Vaticano - Wien 2006, 229-259; G. Penco, 
peryment, dotyczący grupy kapłańsko-monastycznej gromadzącej się w latach 60-tych i 70-tych IV w. w Akwilei wokół kapłana Chromacjusza, który w roku 388 został biskupem tegoż miasta. Akwileja, znajdująca się na północno-wschodnim krańcu Italii, była miastem o strategicznym położeniu, w którym często przebywali cesarze; była ona ważnym ogniwem łączącym Zachód ze światem greckim, miastem posiadającym bardzo aktywny port handlowy na Adriatyku, do którego każdego tygodnia zawijały statki z Aleksandrii i Antiochii. W kontekście kościelnym, obecność dużej społeczności żydowskiej oraz otwarcie na Wschód powodowały, że Akwileja była miastem, w którym krzyżowały się różne prądy. To tu w roku 344 i w 346, w otoczeniu nowego biskupa miasta, Fortunata (biskup ok. 343-370), mieszkał Atanazy z Aleksandrii, zanim powrócił $\mathrm{z}$ drugiego wygnania. $\mathrm{O}$ ile Fortunat, poddawany niewątpliwie silnym naciskom i stykający się bezpośrednio z prądami ariańskimi na swoim terytorium, potępił w $355 \mathrm{r}$. Atanazego i w $357 \mathrm{r}$. podpisał z papieżem Liberiuszem kompromis proariański w Sirmium, to jego następca Walerian ok. 370 r. napisał niezwłocznie po swoim wyborze do Bazylego, aby wyrazić dla niego swój szacunek i wejść z nim w komunię. Grupa duchownych (członków kleru) związana z Walerianem, którą tu się zajmiemy, rozwijała się w podwójnym kontekście: ekspansji życia monastycznego oraz oporu przeciw różnym formom arianizmu.

Źródła dostarczające nam informacji o tym kręgu duchownych z Akwilei są nieliczne, ale pochodzą one z pierwszej ręki, stanowią bowiem świadectwa dwóch osób, które tam żyły i przez pewien czas należały do tego kręgu. Są to świadectwa Hieronima ze Strydonu oraz Rufina, pochodzących z miejscowości położonych niedaleko wielkiego miasta Akwilei.

Świadectwo Hieronima, zawarte w jego listach z roku 374, jest wyrażone także trochę później w Kronice, pisanej ok. 380 r., w której Hieronim odnosi się do trzech lat spędzonych w Akwilei ze swoim dawnym towarzyszem i przyjacielem Bonozjuszem, od 370, gdy obaj w wieku 23 lat opuścili Trewir, w którym przebywali ok. trzech lat po studiach w Rzymie. Do przybycia do Akwilei zachęcili ich prawdopodobnie ich byli towarzysze studiów w stolicy imperium, młodzieńcy pochodzący z tego samego regionu: Rufin i Heliodor.

Ze świadectwa Rufina, którym chciałabym się zająć w pierwszej kolejności, wynika, że w czasie, gdy Hieronim i Bonozjusz wyjechali doskonalić się w Trewirze, będącym wówczas rezydencją cesarską, Rufin dotarł do Akwilei, by tutaj odbyć formację katechumenatu i otrzymać chrzest. Oto tekst pocho-

La vita monastica in Italia all'epoca di S. Martino di Tours, w: Saint Martin et son temps: mémorial du XVI centenaire des débuts du monachisme en Gaule: 361-1961, Studia Anselmiana 46, Roma 1961, 67-83; A. Persic, Aquileia monastica. I primordi eremitico-martiriali e martiniani, il „coro” cromaziano ,, di beati”, le idealità ,terapeutiche” di Girolamo, w: Cromazio di Aquileia: al crocevia di genti e religioni, a cura di S. Piussi, Cinisello Balsamo 2008, 254-267; G. Spinelli, Ascetismo, monachesimo e cenobitismo ad Aquileia nel secolo IV, w: Aquileia nel IV secolo, „Antichità Altoadriatiche" 22 (1982) 273-300. 
dzący z Apologii (401 r.), którą Rufin napisał trzydzieści lat później, odnosząc się do krytyki Hieronima:

„Ja, tak jak wie i on sam (Hieronim) i jak wiedzą wszyscy, już prawie przed trzydziestu laty umieszczony w klasztorze (monasterium) oraz odrodzony przez łaskę chrztu, uzyskałem znamię wiary za pośrednictwem świętych mężów, Chromacjusza, Jowinusa i Euzebiusza, biskupów cieszących się największym rozgłosem i uznaniem w Kościołach Bożych, z których pierwszy [Chromacjusz] był wtedy kapłanem szczęsnej pamięci Waleriana, drugi [Jowinus] archidiakonem, a trzeci [Euzebiusz, młodszy brat Chromacjusza] diakonem i równocześnie ojcem dla mnie oraz nauczycielem zasad wiary. Oni przeto tak mnie nauczyli i tego się trzymam"”.

To, co Rufin chce szczególnie podkreślić, to autorytet całej trójki: Chromacjusz - Jowinus - Euzebiusz (których kolejność odpowiada zapewne nie tylko ich randze w Kościele, ale także ich wiekowi). Jeśli to diakon Euzebiusz, najmniej ważny z nich trzech, był odpowiedzialny za formację katechumenów, to $\mathrm{w}$ jego nauczaniu w nie mniejszym stopniu odbijał się autorytet biskupa Waleriana, którego Chromacjusz był bliskim współpracownikiem. Gdybyśmy dysponowali świadectwem samego tylko Rufina, nie zrozumielibyśmy dobrze związku między stwierdzeniem ,umieszczony w klasztorze” a wzmianką o trzech duchownych. $Z$ tego jednak, co pisze Hieronim, wynika, że ów „klasztor” nie jest czym innym niż domem, w którym Chromacjusz, Jowinus i Euzebiusz prowadzili wspólne życie monastyczne. Przy okazji możemy zauważyć, że odstęp trzydziestu lat we wspomnieniach Rufina może sprawia, iż jego terminologia jest trochę anachroniczna. Moim zdaniem, Rufin używa terminu monasterium dla wygody, ponieważ w $401 \mathrm{r}$. słowo to oznaczało już wspólnotę oddającą się modlitwie i studiowaniu Pisma Świętego ${ }^{10}$.

Świadectwo Hieronima, mniej odległe w czasie, pozwala nam to sprecyzować. Ta swego rodzaju „wspólnota zakonna” w Akwilei w rzeczywistości nie zdołała zatrzymać tych młodych ludzi zafascynowanych ideałem monastycznym: Rufin opuszcza ją w 372 r., aby odwiedzić wspólnoty mnichów w Egipcie (podobnie jak to przed nim uczynił Bazyli), aby spotkać się z Makarym Wielkim, i by znaleźć się w końcu w katechetycznej szkole Dydyma z Aleksandrii; Bonozjusz opuszcza ją w roku następnym, aby prowadzić ży-

\footnotetext{
${ }^{9}$ Rufinus, Apologia contra Hieronymum I 4, ed. M. Simonetti, CCL 20, Turnholti 1961, 39: „Ego, sicut et ipse (Hier.) et omnes norunt, ante annos fere triginta iam in monasterio positus, per gratiam baptismi regeneratus, signaculum fidei consecutus sum per sanctos viros Chromatium, Jovinum et Eusebium, opinatissimos et probatissimos in Ecclesia Dei episcopos, quorum alter tunc presbyter beatae memoriae Valeriani, alter archidiaconus, alius diaconus simulque pater mihi et doctor symboli ac fidei fuit. Illi ergo sic mihi tradiderunt et sic teneo", thum. A. Smaroń, rewizja przekładu A. Caba: Św. Rufin z Akwilei, Obrona przed zarzutami Hieronima, ŹMT 29, Kraków 2004, 47-48.

${ }^{10}$ A. Persić (Aquileia monastica, s. 260) przypuszcza, że pierwsza próba zorganizowania życia monastycznego w Akwilei została podjęta już za czasów biskupa Fortunata (w połowie IV w.); monasterium być może znajdowało się w niewielkiej odległości od miasta.
} 
cie anachorety na niezamieszkałej wyspie na Adriatyku; Hieronim wyjeżdża w tym samym roku (373), niewatpliwie na krótko przed Bonozjuszem, aby dotrzeć do swojej samotni w pobliżu Antiochii w Syrii, gdzie w pewnym momencie dołączy do niego Heliodor, który jednak prędko wróci do północnej Italii i przyjmie obowiązki biskupa Altinum (niedaleko obecnej Wenecji), koło Akwilei.

Pierwsze listy ze zbioru korespondencji Hieronima, zestawione w porządku chronologicznym, adresowane są do jego bliskich z Akwilei lub regionu, począwszy od Rufina (nawet gdy ten ostatni opuścił już Akwileję) ${ }^{11}$. Najważniejszy dla nas list, pochodzący najpewniej z 374 r., to list siódmy, w którym Hieronim oddaje swoją młodą i delikatną siostrę pod opiekę grupy przyjaciół i „braci” (użycie terminu frater w tych listach jest charakterystyczne dla świadomości braterstwa monastycznego u Hieronima). Zanim jednak Hieronim wyrazi swoją prośbę, jego captatio benevolentiae we wstępie listu jest żartem na temat ,trójcy” utworzonej przez Chromacjusza, Jowinusa i Euzebiusza (w tej kolejności), zjednoczonych przez wzajemną miłość (amor mutuus), których ta miłość (caritas) łączy nie mniej niż natura (natura) wiąże dwoje ${ }^{12}$ z nich, do tego stopnia, że są oni - na obraz trzech boskich osób - „Trzema w jednej osobie i jedną osobą w trzech", co też pozwala ich korespondentowi napisać tylko jeden list do trzech odbiorców.

Wreszcie, w końcowym pozdrowieniu Hieronim pochwala grupę, do której jest ono skierowane, której odtwarza częściowo historię i przywołuje tło walki o ortodoksję nicejską:

„Wspólną matkę (która, równa wam w świętości (sanctitate), w tym was wyprzedza, że takich urodziła; i której żywot naprawdę może być złotym nazwany) pozdrawiamy z czcią, która jest wam znana; zarazem objąć należy tym pozdrowieniem wszystkie siostry, które zwyciężyły płeć i świat. One to, przygotowawszy pod dostatkiem oliwy do lamp, oczekują przybycia Oblubieńca. O, błogosławiony dom, w którym przebywają: Anna wdowa, dziewice-prorokinie, bliźniak Samuel, wykarmiony w świątyni! O, szczęśliwe dachy, pod którymi widzimy matkę męczennicę otoczoną wkoło Machabeuszamimęczennikami. Bo aczkolwiek codziennie wyznajecie Chrystusa, gdy Jego przykazania zachowujecie, wy jednak do tej prywatnej chwały dołączyliście też publiczne i otwarte wyznanie, tak, że przez was z waszego miasta wykluczona została trucizna nauki ariańskiej”"13.

${ }^{11}$ Por. St. Rebenich, Hieronymus und sein Kreis, Stuttgart 1992, 42-51.

${ }^{12}$ Tzn. Chromacjusza i Euzebiusza, którzy byli braćmi.

${ }^{13}$ Hieronymus, Epistula 7, 6, ŹMT 54 [wyd. łacińsko-polskie, tekst łac. i oprac. H. Pietras, tłum. J. Czuj, oprac. M. Ożóg, t. 1-5], Kraków 2010, 19-19*: „Matrem communem, quae cum vobis sanctitate societur, in eo vos praevenit, quod tales genuit (cuius vere venter aureus potest dici) eo salutamus honore quo nostis ; una quoque suscipiendas cunctas (is) sorores, quae sexum vicere cum saeculo, quae oleo ad lampadas largiter praeparato sponsi operiuntur adventum. $\mathrm{O}$ beata domus, in qua morantur Anna vidua, virgines prophetissae, geminus Samuel nutritus in templo. O tecta felicia, 
Ten tekst otwiera przed nami wiele dróg. Przede wszystkim należy zwrócić uwagę na szczególny ton Hieronima w tymże 7. liście, ton zdystansowany i trochę humorystyczny w przesadnym wychwalaniu, nawet jeśli jest ono szczere, żarty względem „triady”, do której się zwraca: młody i błyskotliwy Hieronim zdaje się być jakby upojony świeżą wiedzą biblijną i pragnie pokazać ją swoim mistrzom - nie bez kilku zabawnych przeinaczeń.

Pierwsza obserwacja, jaka przychodzi na myśl to ta, iż wszyscy ludzie, których wspomina tu Hieronim, żyją (na sposób monastyczny) w domu rodzinnym Chromacjusza i Euzebiusza, a więc prawdopodobnie wewnątrz miasta, i niedaleko bazyliki powiększonej w połowie IV w. za Fortunata. Aluzja do Anny, wdowy (i prorokini) ze sceny ofiarowania Jezusa w świątyni, która zgodnie z ewangelią Łukasza 2, 36-37, „nie rozstawała się ze świątynią”, jak również odwołanie się dodatkowe do Anny, matki Samuela, z Pierwszej Księgi Królewskiej (wg LXX), której syn został „wykarmiony w świątyni” (por. $1 \mathrm{Sm} 3$ ), wydają się w istocie sugerować, że matka - najprawdopodobniej wdowa - oraz dwaj jej synowie Chromacjusz i Euzebiusz mieszkali w pobliżu akwilejskiej świątyni, i że codziennie ją nawiedzali ${ }^{14}$. Hieronim pomija informację przekazaną w ewangelii przez św. Łukasza w odniesieniu do służebnicy Bożej Anny, która była „prorokinią”; Hieronim woli bowiem zachować to określenie dla „sióstr” w ich zgromadzeniu (cunctae sorores), które porównuje do czterech dziewic i prorokiń, córek ewangelisty Filipa (por. Dz 21, 9). Aluzja do obfitości oliwy do lamp panien roztropnych oczekujących na Oblubieńca (por. Mt 25,4) wskazuje na miejsce, jakie dawały modlitwie i niewątpliwie medytacji Pisma Świętego jako pokarm i podpora ich życia duchowego. Czy naprawdę Chromacjusz i Euzebiusz mieli cztery siostry? Czy także inne dziewice przyłączyły się do nich, aby razem z ich matką prowadzić wspólnie życie zakonne?

Z wyrażonej przez Hieronima pochwały tego „błogosławionego domu” możemy również wywnioskować, że Jowinus, archidiakon diecezji, mieszkał razem z rodziną Chromacjusza; oznaczało to w konsekwencji, że kapłani ci byli celibatariuszami. Odniesienie do „codziennego wyznania (wiary)”, które ofiarowują Chrystusowi, przestrzegając jego przykazań, zakłada przypuszczalnie praktykę rad ewangelicznych: ubóstwa (w postaci wspólnego użytkowania dóbr?), wstrzemięźliwości i posłuszeństwa. Wszyscy oni są począwszy od triady złożonej z kapłana, archidiakona i diakona, bliskimi współpracownikami biskupa Waleriana; Hieronim nalega bowiem na to, by nie tylko adresaci jego listu lecz także Walerian (którego prosi za ich pośrednictwem) napisali do jego młodszej siostry, dodając jej odwagi. Z kolei, co do subdiakona Nice-

in quibus cernimus Machabaeorum coronis cinctam martyrem matrem. Nam licet quotidie Christum confiteamini, dum eius praecepta servatis, tamen ad privatam gloriam publica haec accessit vobis et aperta confessio, quod per vos ab urbe vestra Ariani quondam dogmatis virus exclusum est".

${ }^{14}$ Podobnie Paulin z Noli (Carmen 21, ed. W. Hartel, CSEL 30, Vindobonae 1894, 167, wiersz 316), który mieszkał w pobliżu sanktuarium św. Feliksa, nawiązał do przykładu Samuela. 
asa i mnicha Chryzogona - mieszkających w Akwilei i będących adresatami dwóch listów z tego samego okresu, co list do Chromacjusza i jego bliskich to nie wydaje się, by mieszkali oni razem z nimi, gdyż Hieronim nie prosi ich o przekazanie im pozdrowień. Powstaje więc pytanie: gdzie mieszkali Rufin, Hieronim, Bonozjusz (i być może Heliodor) w czasie ich pobytu w Akwilei? Czy należy myśleć, że posiadłość rodzinna matki Chromacjusza, podobnie jak posiadłość matki Bazylego w Annesis, została przekształcona w klasztor, na przykład w połowie szóstej dekady IV w.? Czy, wręcz przeciwnie, biorąc dosłownie określenie Rufina, należy przypuszczać, iż rzeczywiście istniał tam „klasztor” (monasterium) w ścisłym znaczeniu tego słowa, odrębny od domu Chromacjusza, lecz w takim razie, któż miałby tam mieszkać poza tymi młodymi ludźmi, wciąż nie bardzo doświadczonymi, których imiona znamy?

Nie należy również lekceważyć wmieszania tej grupy w konflikty religijne tych trudnych lat. O ile Fortunat zmieniał swoje nastawienie, to wydaje się, że Chromacjusz i jego otoczenie, podobnie jak następca Fortunata biskup Walerian, pozostawali zawsze mocno przywiązani do wiary zgodnej z nauką Soboru Nicejskiego, i że reprezentowali swoje poglądy publicznie i skutecznie (bez wątpienia w 373 r.), mimo iż napotkali wcześniej na sprzeciw, a nawet byli prześladowani, jak to sugeruje porównanie matki Chromacjusza i jej dzieci z matką Machabeuszy ze swoimi synami ${ }^{15}$. Dlatego do prywatnego wyznania życia ewangelicznego dla Chromacjusza i jego bliskich dodaje się i jego apostolskie wyznanie wiary, albo poprzez jej głoszenie ludowi, albo, być może poprzez publiczną dyskusję ze zwolennikami arian.

Kolejne światło, choć bardzo skromne, na temat tej grupy rzuca Hieronim w swojej Kronice, będącej kontynuacją kroniki Euzebiusza z Cezarei. Hieronim ukończył ją w roku 380. Pod rokiem 374 napisał tam między innymi: „Duchowni w Akwilei uważani są za chór błogosławionych"16.

Należy zauważyć, że Hieronim nie mówi o „mnichach” (lub „klasztorze”), ale odnosi się najwyraźniej do wspólnego życia duchownych, którymi byli Chromacjusz, Jowinus i Euzebiusz, a razem z nimi być może jeszcze inni. To, że rozróżnia Hieronim te dwa style życia wynika z nieco późniejszej wskazówki (rok 377), którą daje w związku z dwoma, być może trzema, byłymi członkami kręgu z Akwilei:

„Florentyn, Bonozjusz i Rufin uważani są za wybitnych mnichów (monachi); Florentyn okazał tak wielkie miłosierdzie dla potrzebujących, iż został nazwany «ojcem ubogich»" ${ }^{17}$.

${ }^{15}$ Matka siedem braci (2Mch 7) była „typem” Kościoła prześladowanego, por. L.F. Pizzolato P. Somenzi, I sette fratelli Maccabei nella Chiesa antica d'Occidente, Studia Patristica Mediolanensia 25, Milano 2005.

${ }^{16}$ Hieronymus, Chronicon, rok 374, ed. R. Helm, GCS 47, Eusebius Werke 7, Berlin 1956, 240 : „Aquileienses clerici, quasi chorus beatorum habentur", thum. własne

${ }^{17}$ Tamże, rok 377, GCS 47, 248: ,Florentinus et Bonosus (Bonosius) et Rufinus insignes mona- 
Można z tego wnioskować, że dla Hieronima, duchowni z Akwilei i ich bliscy wiodą święte życie zapewne we wspólnocie, ale nie są „mnichami” w ścisłym znaczeniu tego słowa - w każdym razie nie są nimi zgodnie z etymologią tego słowa, odwołującą się do samotności i odsunięcia od życia świeckiego: aby tak naprawdę stać się „mnichem” w oczach Hieronima, trzeba, jak się wydaje, odłączyć się od grupy cenobitów i próbować osobistego doświadczenia, praktykując życie pustelnicze jak Bonozjusz, oddając się na służbę Pismu Świętemu jak Rufin (i Hieronim), bądź też wyświadczając miłosierdzie wobec potrzebujących, jak to w sposób heroiczny czynił Florentyn.

Jeśli chodzi o wyrażenie chorus beatorum, to wskazuje ono na harmonię życia wspólnego, opartą na „więzi” miłości (zob. glutinum caritatis lub glutinum Christi w listach Hieronima $\mathrm{z}$ tego okresu ${ }^{18}$ ). Pojęcie chorus, które przywołuje pierwotnie na myśl grecką poezję chóralną (Pindar), mającą charakter responsoryjny (dwa pół-chóry odpowiadają sobie nawzajem, a następnie łączą się ze sobą), wskazuje także na ważność modlitwy wspólnej, niewątpliwie śpiewanej, oraz na miejsce liturgii w życiu monastycznym, w całym jego niebiańskim, względnie anielskim wymiarze, oraz w wymiarze eschatologicznym, jak daje to do zrozumienia odwołanie się do przypowieści o pannach (dosł. dziewicach) czekających na przyjście Oblubieńca. Co do sposobu życia tych „chórów”, możemy przypuszczać, że to, co pisze Ambroży o wspólnocie z Vercelli, było prawdziwe również w Akwilei:

„[sprawiaja] oni, że w dzień i w nocy rozbrzmiewają hymny - na tym bowiem polega życie anielskiej milicji: nieustannie uwielbiać Boga, modlić się i stawać się miłym Panu przez częste modlitwy - oddają się oni lekturze [Pisma Świętego] i zajmują umysł nieustanną pracą" $"$.

Ostatni aspekt życia grupy duchownych z Akwilei nie jest w sposób wyraźny wspomniany przez Hieronima; został on jednak przywołany przez Ambrożego w odniesieniu do wspólnoty duchownych z Vercelli, wyłania się on także z tego wszystkiego, co wiemy skądinąd o Chromacjuszu i jego bliskich. Otóż studiowanie Pisma Świętego i, szerzej mówiąc, literatury chrześcijańskiej, zajmowało w tej grupie ważne miejsce. Widać to nie tylko w powołaniach, jakie zostały wzbudzone u Rufina i Hieronima podczas pobytu w Akwilei; ale

chi habentur, e quibus Florentinus tam misericors in egentes fuit, ut vulgo pater pauperum vocatus sit", thum. własne.

${ }^{18}$ Słowo chorus pierwotnie służyło na oznaczenie zespołów filozoficznych, szczegolnie w szkole epikurejskiej. Zob. J.-M. André, Les écoles philosophiques aux deux premiers siècles de l'empire, w: Aufstieg und Niedergang der Römischen Welt, vol. 2: Prinzipat, hrsg. von W. Haase, Bd. 36, Philosophie, Wissenschaften, Technik, 1. Teilband, Philosophie, Historische Einleitung Platonismus, Berlin - New York 1987, 7.

${ }^{19}$ Ambrosius Mediolanensis, Epistula extra coll. 14, 82, CSEL 82, 279: „,hymnis dies ac noctes personant. Haec nempe angelorum militia est: semper esse in Dei laudibus, orationis crebris conciliare atque exorare Dominum, student lectioni vel operibus continuis mentem occupant", thum. własne. 
widać to przede wszystkim w pismach samego Chromacjusza, świadczących o dobrej znajomości świętych tekstów, oraz w roli, jaką Chromacjusz, po objęciu urzędu biskupa, pełnił razem z biskupem Heliodorem z sąsiedniej diecezji Altinum względem tych dwóch uczonych, Rufina i Hieronima, prosząc ich o thumaczenia oraz o komentarze do ksiąg biblijnych ${ }^{20}$, tworząc stopniowo w chwili, gdy barbarzyńskie inwazje zagrażały imperium i jego kulturze - bibliotekę chrześcijańską w języku łacińskim przeznaczoną do tego, aby przekazać Kościołowi Zachodniemu egzegetyczne i historyczne bogactwo greckiego chrześcijaństwa.

\section{$* * *$}

Reasumując, źródła, które udzielają nam informacji o grupie duchownych z Akwilei, pozostawiają nam więcej pytań, niż dają precyzyjnych odpowiedzi. Nie wiemy w szczególności, czy miejsce przebywania tych duchownych zasługiwało na miano monasterium, jakie zdaje mu się nadawać Rufin, i czy było ono otwarte także dla braci i sióstr nie należących do najbliższego otoczenia Chromacjusza. Tym niemniej jednak, ze źródeł tych wynika niezaprzeczalnie, że Chromaciusz, Jowinus i Euzebiusz, duchowni Kościoła w Akwilei wraz z matką Chromacjusza i Euzebiusza oraz ich siostrami prowadzili życie wspólne, które dzięki przestrzeganiu rad ewangelicznych stanowiło „codzienne wyznanie wiary". Prawdopodobnie miało to miejsce w domu rodzinnym Chromacjusza, niedaleko bazyliki biskupiej, i zakładało możliwe połączenie między życiem , „chóru błogosławionych” a działalnością apostolską, taką jak: przygotowanie katechumenów przez Euzebiusza, które potwierdza Rufin; publiczne nauczanie Chromacjusza, wspominane przez Hieronima, a także poświadczony udział Chromacjusza u boku Waleriana i Ambrożego, w synodzie w Akwilei w 381 r., który odrzucił arianizm i przywrócił wiarę nicejską. Jest rzeczą pewna - jak świadczy o tym Ambroży, używając w odniesieniu do wspólnoty z Vercelli oksymoronu ,miejscy mnisi (in civitate monachi)" ${ }^{21}$ - że istniał pewien rodzaj sprzeczności - ale uzupełniającej - między położeniem wspólnoty w samym sercu miasta, a wycofaniem się zeń, by przebywać z Bogiem; sprzeczności między publicznym wymiarem życia duszpasterzy ,jak w jakimś teatrze (velut in quodam theatro) a stosowaniem, w ukryciu

${ }^{20}$ Oprócz komentarzy, o które Chromacjusz sam prosił Hieronima (do ksiag Habakkuka i Jonasza) lub wraz z Heliodorem (do ksiąg Ozeasza, Amosa, Zachariasza i Księgi Królów), są też tłumaczenia, o które Chromacjusz prosił Hieronima: Księgi Kronik, Ksiąg Tobiasza i Judyty oraz trzech ksiąg Salomona [Księgi Przysłów, Mądrości Syracha i Pieśni nad Pieśniami] (ta ostatnia praca była równocześnie dedykowana Heliodorowi). Wśród tłumaczeń, o które prosił Chromacjusz Rufina, można przytoczyć homilie Orygenesa o Księdze Jozuego oraz Historię kościelnq Euzebiusza z Cezarei.

${ }^{21}$ Ambrosius Mediolanensis, Epistula extra coll. 14, 66, CSEL 82, 270: „,versantes intra urbem abdicet usu urbis et conversatione". 
(in secreto) praktyk ascetycznych"22. Temu właśnie powiązaniu życia monastycznego i apostolskiego, myśl Chromacjusza zawdzięcza, moim zdaniem, swą nadzwyczajną równowagę, która wydawała się jednak niewystarczająco radykalna dla Bonozjusza, Rufina i Hieronima, a w oczach tych dwóch ostatnich, niewystarczająco poświęcona nie tylko ascezie i modlitwie, ale także pogłębionej pracy intelektualnej. Jednakże, doświadczenia Vercelli i Akwilei, w ich oryginalności, zostały na nowo podjęte i uporządkowane przez Augustyna w Hipponie. Korzystając z tych doświadczeń, Augustyn ustalił reguły kanoników, których to reguł płodność na Zachodzie jest niezaprzeczalna.

\section{AQUILEIENSES CLERICI QUASI CHORUS BEATORUM HABENTUR (JEROME, THE CHRONICLE, AD 374). \\ AN EXAMPLE OF MONASTIC LIFE OF PRIESTS TOWARDS THE END OF THE $4{ }^{\mathrm{TH}}$ CENTURY}

\section{(Summary)}

The end of the fourth century sees the emergence, in the West, of several experiences of monastic life in the city for the bishop and a part of his presbyterium (Eusèbe of Vercelli, Martin of Tours, Paulin of Nola, Augustin of Hippo). A similar attempt, around the priest Chromace of Aquileia (before his episcopate, and maybe even later), is documented by some testimonies of Jerome from Stridon and Rufin from Aquileia for the years 370s. These testimonies are the object of the present study.

Key words: monastic life, bishops and presbyterium, Aquileia, St Jerome.

Slowa kluczowe: życie monastyczne, biskupi i prezbiterzy, Akwileja, św. Hieronim.

\section{BIBLIOGRAFIA}

\section{Źródła}

Ambrosius Mediolanensis, Epistulae, ed. M. Zelzer, CSEL 82, Vienne 1982.

Augustinus, Sermo 5, PL 40, 1242-1246.

Cyprianus, Epistulae, ed. Bayard (Chanoine): Cyprien, Correspondance, vol. 2, Les Belles Lettres, Paris 1925.

Hieronymus, Chronicon, ed. R. Helm, GCS 47, Eusebius Werke 7, Berlin 1956.

Hieronymus, Epistulae, ŹMT 54, 55, 61, 63 i 68 [wyd. łacińsko-polskie, tekst łac. i oprac.

H. Pietras, thum. J. Czuj, oprac. M. Ożóg, t. 1-5], Kraków 2010-2013. Paulinus Nolanus, Carmina, ed. W. Hartel, CSEL 30, Vindobonae 1894.

${ }^{22}$ Tamże 14, 71, GCS 82, 273, thum. własne. Por. Augustinus, Sermo 5, PL 40, 1246: ,ut solitarie etiam in civitate viventes habitare possemus in placito sancto". 
Possidius, Vita Augustini, PL 32, 33-66.

Rufinus, Apologia contra Hieronymum, ed. M. Simonetti, CCL 20, Turnholti 1961, 29123, tłum. A. Smaroń, rewizja przekładu A. Caba: Św. Rufin z Akwilei, Obrona przed zarzutami Hieronima, ŹMT 29, Kraków 2004, 45-150.

\section{Opracowania}

ANDRÉ J.-M., Les écoles philosophiques aux deux premiers siècles de l'empire, w: Aufstieg und Niedergang der Römischen Welt, vol. 2: Prinzipat, hrsg. von W. Haase, Bd. 36, Philosophie, Wissenschaften, Technik, 1. Teilband, Philosophie, Historische Einleitung Platonismus, Berlin - New York 1987, 5-77.

Bratož R., Frühes Mönchtum in den Donau- und Balkanprovinzen. Eine Bestandsaufnahme, w: Acta congressus internationalis XIV archaeologiae Christianae, a cura di R. Harreither - Ph. Pergola - R. Pillinger - A. Pülz, pars 1, Città del Vaticano - Wien 2006, 229-259.

Cattaneo E., I ministeri nella Chiesa antica. Testi patristici dei primi tre secoli, Milano 1997 = Les ministères dans l'Église ancienne, Paris 2017.

Cattaneo E., Una lettura sacerdotale dei salmi, „La civiltà cattolica” nr 3898 (2012) 4, 343-353.

LiEnhard J.T., Paulin de Nole, DSp XII 592-602.

Penco G., La vita monastica in Italia all'epoca di S. Martino di Tours, w: Saint Martin et son temps: mémorial du XVI centenaire des débuts du monachisme en Gaule: 3611961, Studia Anselmiana 46, Roma 1961, 67-83.

Persic A., Aquileia monastica. I primordi eremitico-martiriali e martiniani, il „,coro” cromaziano ,, di beati”, le idealità ,, terapeutiche” di Girolamo, w: Cromazio di Aquileia: al crocevia di genti e religioni, a cura di S. Piussi, Cinisello Balsamo 2008, 254-267.

Persic A., Basilio monaco e vescovo: una sola chiamata per tutti $i$ cristiani, w: Per foramen acus. Il cristianesimo antico di fronte alla pericope evangelica del ,giovane ricco”, Studia Patristica Mediolanensia 14, Milano 1986, 160-207.

Pizzolato L.F. - Somenzi P., I sette fratelli Maccabei nella Chiesa antica d'Occidente, Studia Patristica Mediolanensia 25, Milano 2005.

Rebenich St., Hieronymus und sein Kreis, Stuttgart 1992.

SpInelli G., Ascetismo, monachesimo e cenobitismo ad Aquileia nel secolo IV, w: Aquileia nel IV secolo, „Antichità Altoadriatiche” 22 (1982) 273-300. 
